\title{
PENGARUH HARGA, PROMOSI, DAN KUALITAS PELAYANAN TERHADAP LOYALITAS PELANGGAN DIMEDIASI KEPUASAN PELANGGAN PADA KONSUMEN GOJEK
}

\author{
Fifin Anggraini \\ Manajmen, Sekolah Tinggi Ilmu Ekonomi Indonesia (STIESIA) Surabaya \\ fifinanggraini@gmail.com \\ Anindhyta Budiarti \\ Manajmen, Sekolah Tinggi Ilmu Ekonomi Indonesia (STIESIA) Surabaya \\ anindhytabudiarti@stiesia.ac.id
}

\begin{abstract}
Abstrak
Loyalitas pelanggan merupakan aspek yang sangat penting, maka dari itu dibutuhkan upaya untuk meningkatkan loyalitas pelanggan dengan menggunakan beberapa aspek pendukung seperti harga, promosi, kualitas pelayanan dan kepuasan pelanggan. Penelitian ini bertujuan untuk menguji pengaruh harga, promosi, kualitas pelayanan terhadap loyalitas pelanggan yang dimediasi kepuasan pelanggan atas jasa yang diberikan oleh Gojek. Jenis penelitian ini penelitian kuantitatif. Sampel yang diperoleh dalam penelitian ini menggunakan purposive sampling. Jumlah sampel yang digunakan dalam penelitian ini sebanyak 100 sampel. Metode analisis yang digunakan adalah analisis jalur (path analysis). Hasil penelitian ini menunjukkan bahwa harga berpengaruh sigifikan dan positif terhadap kepuasan pelanggan. Promosi berpengaruh sigifikan dan positif terhadap kepuasan pelanggan. Kualitas pelayanan berpengaruh sigifikan dan positif terhadap kepuasan pelanggan. Harga berpengaruh sigifikan dan positif terhadap loyalitas pelanggan. Promosi berpengaruh tidak signifikan dan positif terhadap loyalitas pelanggan. Kualitas pelayanan berpengaruh positif dan signifikan terhadap loyalitas pelanggan. Harga berpengaruh terhadap loyalitas pelanggan dimediasi kepuasan pelanggan. Promosi berpengaruh terhadap loyalitas pelanggan dimediasi kepuasan pelanggan. Kualitas pelayanan berpengaruh terhadap loyalitas pelanggan dimediasi kepuasan pelanggan. Kepuasan pelanggan berpengaruh signifikan dan positif terhadap loyalitas pelanggan.
\end{abstract}

Kata Kunci: Harga, Promosi, Kualitas Pelayanan, Kepuasan Pelanggan, Loyalitas Pelanggan

\begin{abstract}
Since customer loyalty is the most important aspects, some attempts are needed to increase this loyalty such as price, promotion, service quality and customers' satisfaction. This research aimed to examine the effect of price, promotion, service quality on customers' loyalty which intervened by customers' satisfaction of Gojek's service. This research was quantitative. While the data collection technique used purposive sampling. In line with, there were 100 respondents. Moreover, the data analysis technique used path analysis. The research result concluded price had positive and significant effect on customers' satisfaction. Promotion had positive and significant effect on customers' satisfaction. Service quality had positive and significant on customers' satisfaction. Price had positive and significant effect on customers' loyalty. Promotion had positive and insiginficant effect on customers' loyalty. Service quality had positive and significant effect on customers' loyalty. Furthermore, price as well as promotion affected customers' loyalty which was intervened by customers' satisfaction. Likewise, service quality affected customers' loyalty which was intervened by custoers' satisfaction. In brief, customers' satisfaction had positive and significant effect on customers' loyalty.
\end{abstract}

Keywords: Price, Promotion, Service Quality, Customers' Satisfaction, Customers' Loyalty

\section{PENDAHULUAN}

Perkembangan ekonomi saat ini berkembang dengan pesat, sehingga banyak bermunculan persaingan usaha-usaha baru, khususnya pada perusahaan yang bergerak pada bidang yang sama. Persaingan yang semakin ketat menuntut para pelaku bisnis untuk memiliki keunggulan tersendiri agar dapat memikat konsumen sehingga dapat bersaing di pasar. Begitu juga dengan usaha dibidang transportasi online. Transportasi merupakan sarana yang sangat dibutuhkan, karena dengan adanya transportasi dapat mengefektifkan pekerjaan dan membantu dalam memenuhi kebutuhan sehari-hari. Ketergantungan masyarakat terhadap transportasi sangat tinggi, dengan alasan mempersingkat waktu. Tetapi untuk mengakses kendaraan umum akan menghabiskan lebih banyak waktu karena harus melalui terminal, stasiun atau bandara.

Perkembangan sosial dan budaya masyarakat yang semakin maju dan modern, sehingga banyak masyarakat yang menyukai hal-hal yang serba instan, yaitu transportasi online. Beberapa perusahaan yang bergerak dibidang transportasi online adalah Gojek, Grab, Blue Bird dan lain-lain. Dengan adanya persaingan 
yang semakin ketat menuntut perusahaan-perusahaan tersebut untuk mempertahankan pangsa pasarnya dan juga harus mampu untuk memenuhi kebutuhan, keinginan, dan permintaan konsumennya. Perusahaan ojek online yang sedang berkembang pesat di Surabaya yaitu Gojek, Gojek merupakan perusahaan yang didirikan oleh anak bangsa yang bernama Nadiem Makarim bersama temannya Michaelangelo Moran pada bulan Maret 2014.

Gojek merupakan salah satu jasa penyedia transportasi online yang mampu mempertahankan pangsa pasarnya pada kondisi persaingan transportasi online yang semakin ketat. Gojek mulai meningkatkan kualitas pelayanannya dengan menambah jasa layanan seperti Go Ride (Jasa Angkutan), Go Food (Jasa Kurir Makanan/Minuman), Go Send (Jasa Antar Barang), Go Tix (Jasa Pemesanan Tiket Konser dan Sejenisnya), Go Box (Jasa Pengiriman Barang Dalam Skala Besar), Go Clean (Jasa Pembersih Rumah/Kantor) dan masih banyak lagi jasa lainnya yang diberikan oleh Gojek. Cara pemesanan yang lebih efektif dan efisien akan memudahkan para pelanggan dalam kegiatan sehari-hari dan Gojek siap untuk melayani pelanggan dimana saja.

Mengingat semakin banyaknya ojek online berdampak pada semakin ketatnya persaingan yang menuntut Gojek untuk memperhatikan beberapa strategi harus dilakukan oleh perusahaan untuk menekan para pesaing yang mulai tumbuh. Untuk meningkatkan minat konsumen ditengah persaingan salah satunya adalah dengan meningkatkan loyalitas konsumen. Untuk mendukung terciptanya sifat loyal konsumen terhadap gojek maka dibutuhkan suatu kepuasan akan jasa yang diberikan. Terdapat beberapa penelitian yang mendukung dan menyatakan bahwa kepuasan pelanggan memiliki pengaruh positif dan signifikan terhadap loyalitas konsumen antara lain, hasil penelitian dari Azhar et al (2019), Dennisa (2016), Khakim et al (2014), Sembiring et al (2014). Dari hasil penelitian yang sudah ada maka peneliti menggunakan variabel kepuasan pelanggan dalam penelitian sekarang.

Terdapat beberapa faktor seperti harga, promosi, kualitas layanan dan kepuasan pelanggan yang menunjang terciptanya loyalitas pelanggan terhadap Gojek. Beberapa faktor penunjang tersebut dapat menjadi pilihan konsumen untuk memilih jasa mana yang akan digunakan. Beberapa penelitian yang mendukung dan menemukan bahwa harga memiliki pengaruh positif dan signifikan terhadap loyalitas pelanggan di mediasi kepuasan pelanggan antara lain, hasil penelitian dari Azhar et al (2019), Yulianto et al (2016) dan Khakim et al (2014).

Dalam merancang strategi pemasaran, perusahaan harus selalu berorientasi kepada pelanggan mulai dari menemukan produk yang diinginkan oleh pelanggan, motif dan kebiasaan membeli serta menentukan harga sesuai dengan daya beli pelanggan, menentukan saluran distribusi dan akhirnya menentukan program promosi dalam usaha meningkatkan penjualan. Penelitian yang mendukung dan menyatakan bahwa promosi memiliki pengaruh positif dan signifikan terhadap loyalitas pelanggan yang di mediasi kepuasan pelanggan antara lain, hasil penelitian dari hasil penelitian Tjahjaningsih (2013). Sedangkan hasil berbeda ditunjukkan oleh Novianti et al (2018) yang menyatakan bahwa promosi mempunyai pengaruh tidak langsung positif dan signifikan terhadap loyalitas pelanggan melalui kepuasan pelanggan.

Dalam meningkatkan loyalitas pelanggan pada perusahaan jasa termasuk Gojek, dibutuhkan kualitas pelayanan yang baik dan memuaskan sesuai kebutuhan dan keinginan konsumen. Terdapat beberapa penelitian yang mendukung dan menyatakan bahwa kualitas pelayanan memiliki pengaruh positif dan signifikan terhadap loyalitas pelanggan yang di mediasi kepuasan pelanggan antara lain, hasil penelitian dari Dennisa (2016), Yulianto et al (2016), Sembiring et al (2014) dan Khakim et al (2014). Dengan adanya penelitian tersebut maka diketahui bahwa kualitas pelayanan merupakan faktor yang berpengaruh terhadap loyalitas pelanggan. Dapat disimpulkan bahwa kualitas pelayanan (service quality) memiliki kontribusi yang sangat penting untuk keberhasilan suatu perusahaan.

Loyalitas terbentuk melalui proses belajar dan hasil pengalaman seorang konsumen yang telah melakukan pembelian secara konsisten sepanjang waktu. Pembelian akan terus berukang apabila yang didapat sudah sesuai dengan harapan dan keinginan, hal ini dapat dikatakan bahwa telah timbul kesetiaan pelanggan. Perilaku pembelian ulang semata mata menyangkut pembelian merek tertentu yang sama secara berulang kali (bisa dikarenakan memang hanya satu satu nya merk yang tersedia, merk termurah dan sebagainya) (Tjiptono, 2011). Dapat disimpulkan bahwa loyalitas timbul karena adanya kepuasan terhadap suatu merek tertentu yang memenuhi kriteria yang diinginkan dan akan melakukan pembelian secara terus-menerus. Pelanggan dikatakan setia atau loyal apabila pelanggan tersebut menujukkan perilaku pembelian secara teratur atau terdapat suatu kondisi dimana mewajibkan pelanggan membeli paling sedikit dua kali dalam selang waktu tertentu.

Untuk menimbulkan loyalitas pelanggan dibutuhkan rasa puas pelanggan terlebih dahulu terhadap suatu produk tertentu. Kepuasan konsumen merupakan target setiap perusahaan. Kepuasan konsumen adalah evaluasi purnabeli antara persepsi terhadap kinerja altenatif produk atau jasa yang dipilih memenuhi atau melebihi harapan. Apabila persepsi terhadap kinerja tidak bisa memenuhi harapan, maka yang terjadi adalah ketidak puasan (Tjiptono, 2014). Sehingga dapat dikataka bahwa kepuasan pelanggan adalah hasil evaluasi dari konsumen terhadap produk atau jasa yang dikonsumsi sesuai dengan harapan. Harapan pelanggan merupakan perkiraan pelanggan tentang apa yang akan didapat apabila membeli atau mengkonsumsi suatu produk.

Untuk memenuhi kepuasan pelanggan maka perusahaan juga harus memperhatikan harga yang ditawarkan kepada pelanggan serta apa saja yang akan didapat dengan sejumlah harga tersebut. Harga merupakan faktor penting bagi perusahaan untuk mendapatkan keuntungan dan juga untuk memikat pelanggan. Setiap perusahaan berusaha menetapkan harga yang dapat dijangkau oleh konsumen agar lebih 
unggul dari para pesaingnya. Harga adalah jumlah rupiah yang bisa dibayar oleh pasar (Colin, 2011). Dari pernyataan tersebut harga dapat dikatakan sebagai suatu ukuran alat tukar agar memperoleh hak kepemilikan atau penggunaan suatu produk barang atau jasa. Hal ini menunjukkan bahwa konsumen akan semakin selektif dalam memilih salah satu dari banyaknya alternatif ojek online yang sesuai dengan keinginan dan kebutuhan.

Selain faktor harga, dalam pemenuhan kepuasan konsumen serta peningkatan loyalitas konsumen tidak hanya dengan memperhatikan dan meningkatkan kualitas pelayanan perusahaan saja, akan tetapi terdapat cara lain, yaitu perusahaan dapat melakukan kegiatan promosi. Promosi yang menarik dan komunikatif akan dapat diterima dengan baik oleh pelanggan. Promosi merupakan suatu ungkapan dalam arti luas tentang kegiatan-kegiatan yang secara efektif dilakukan oleh perusahaan (penjual) untuk mendorong konsumen membeli produk atau jasa yang ditawarkan (Sukirno dan Poerwanto, 2014:194). Perusahaan harus berperan aktif dalam kegiatan promosi, karena promosi merupakan informasi yang diberikan oleh perusahaan kepada konsumen mengenai apa saja produk yang ditawarkan dan apa saja keuntungan yang akan didapatkan oleh pelanggan apabila membeli atau mengkonsumsi produk tersebut.

Sebagai perusahaan yang bergerak di bidang jasa, Gojek meningkatkan kualitas pelayanan sebagai poin utama. Dengan kualitas pelayanan yang semakin unggul maka konsumen akan menunjukkan rasa puasnya terhadap suatu jasa tersebut sehingga mempengaruhi timbulnya loyalitas pelanggan. Menurut Parasuraman dalam Lupiyoadi (2013) mengatakan bahwa kualitas pelayanan yaitu seberapa jauh perbedaan antara kenyataan dan harapan pelanggan atas pelayanan yang mereka terima. Kualitas Pelayanan menurut (Christina, 2013) merupakan perspektif konsumen dalam jangka panjang dan merupakan evaluasi kognitif dari jasa transfer. Jadi kualitas pelayanan yang baik akan memberikan dampak positif bagi perusahaan karena kualitas pelayanan akan menjadi penilaian konsumen apakah pelayanan yang diberikan memuaskan dan memenuhi keinginan atau belum. Kualitas pelayanan yang buruk akan menggiring konsumen untuk beralih menggunakan perusahaan jasa lainnya yang menurut mereka lebih baik.

Sesuai dengan uraian latar belakang di atas, maka rumusan masalah dalam penelitian ini dapat disusun sebagai berikut 1) Apakah Harga berpengaruh terhadap Kepuasan Pelanggan Gojek?, 2) Apakah Promosi berpengaruh Kepuasan Pelanggan Gojek?, 3) Apakah Kualitas Pelayanan berpengaruh Kepuasan Pelanggan Gojek?, 4) Apakah Harga berpengaruh terhadap Loyalitas Pelanggan Gojek?, 5) Apakah Promosi berpengaruh terhadap Loyalitas Pelanggan Gojek?, 6) Apakah Kualitas Pelayanan berpengaruh terhadap Loyalitas Pelanggan Gojek?, 7) Apakah Harga berpengaruh terhadap Loyalitas Pelanggan dimediasi Kepuasan Pelanggan Gojek?, 8) Apakah Promosi berpengaruh terhadap Loyalitas Pelanggan dimediasi Kepuasan Pelanggan Gojek?, 9) Apakah Kualitas
Pelayanan berpengaruh terhadap Loyalitas Pelanggan dimediasi Kepuasan Pelanggan Gojek?, 10) Apakah terdapat pengaruh Kepuasan Pelanggan terhadap Loyalitas Pelanggan Gojek?.

\section{METODE}

Jenis penelitian ini adalah penelitian kuantitatif. Adapun metode dari penelitian ini dengan menggunakan metode survei yaitu suatu metode pengumpulan data yang menggunakan instrumen kuesioner untuk mendapatkan tanggapan dari responden yang menjadi sampel penelitian. Pada penelitian ini populasi yang diambil adalah mahasiswa Sekolah Tinggi Ilmu Ekonomi Indonesia (STIESIA) Surabaya.

Metode pengumpulan data yang digunakan dalam penelitian ini adalah kuesioner. Dalam penelitian ini data diperoleh dengan cara mendatangi seluruh responden dan memberikan angket atau kuesioner untuk diisi responden, kemudian responden mengisi jawaban pertanyaan dalam angket, serta mengumpulkan kembali angket yang telah diisi. Pada penelitian ini menggunakan purposive sampling yaitu dengan memberikan batasanbatasan kepada responden yang memenuhi kriteria sebagai berikut:

(1) Mahasiswa Sekolah Tinggi Ilmu Ekonomi Indonesia (STIESIA) Surabaya semester 4, 6, dan 8

(2) Mahasiswa Sekolah Tinggi Ilmu Ekonomi Indonesia (STIESIA) Surabaya yang menggunakan aplikasi Go-Jek 1-2 kali atau lebih.

Variabel harga dalam penelitian ini diukur dengan empat indikator yang merujuk pada teori Kotler dan Armstrong (2008:278) yaitu, (1) Keterjangkauan harga pada Gojek dengan daya beli kosumen, (2) Kesesuaian harga dengan kualitas produk yang diberikan oleh Gojek, (3) Daya saing harga pada aplikasi Gojek yang lebih terjangkau dibanding dengan perusahaan yang sejenis, (4) Kesesuaian harga dengan manfaat yang diberikan oleh Gojek. Variabel promosi dalam penelitian ini diukur dengan tiga indikator yang merujuk pada teori Kotler dan Keller (2016:623) yaitu, (1) Konsumen tertarik pada promosi diskon yang ditawarkan oleh Gojek. Untuk kupon atau voucher potongan harga, didapatkan oleh konsumen atas pembayaran tertentu produk Gojek dan kupon atau voucher potongan harga tersebut dapat digunakan konsumen berdasarkan kode promo yang diberikan oleh Gojek, (2) Konsumen tertarik pada promosi iklan Gojek. Gojek menggunakan beberapa media dalam melakukan kegiatan promosi periklanan, yaitu: radio, spanduk, brosur, poster, web site, media sosial dan pensponsoran (event), (3) Konsumen tertarik pada promosi kontes yang diselenggarakan oleh Gojek. Gojek mengadakan kontes dengan cara mengunggah foto atau video dengan tema tertentu untuk memenangkan sejumlah hadiah. Variabel kualitas pelayanan dalam penelitian ini diukur dengan lima indikator yang merujuk pada teori Zeithaml dan M. J. Bitner dalam Tjiptono (2008:58-69) yaitu, (1) Tangibles (berwujud), meliputi penampilan fasilitas fisik seperti keadaan kendaraan yang 
dipakai oleh driver,kebersihan, kerapihan, kenyamanan, dan penampilan driver, (2) Reliability (kehandalan), yakni kemampuan driver memberikan layanan yang dijanjikan dengan segera, kemampuan mengemudi, akurat dan memuaskan, (3) Responsiveness (ketanggapan), yaitu kesediaan para driver untuk membantu para pelanggan dan memberikan layanan dengan tepat waktu, (4) Assurance (jaminan atau kepastian), meliputi jaminan keamanan dan kenyamanan yang diberikan oleh driver Gojek saat berkendara, (5) Empathy (empati), yaitu kemampuan driver dalam memberikan perhatian, keramah-tamahan, dan kesopanan. Variabel kepuasan pelanggan dalam penelitian ini diukur dengan empat indikator yang merujuk pada teori Irawan (2009:3) yaitu, (1) Kepuasan pelanggan terhadap jasa yang diberikan oleh Gojek, (2) Menggunakan kembali jasa Gojek, (3) Variabel kepuasan pelanggan dalam penelitian ini diukur dengan lima indikator yang merujuk pada teori Kotler dan Keller (2016:650) yaitu, (1) Satisfaction, Tetap menggunakan jasa Gojek selama ekspektasi dan kepuasn terpenuhi serta kesesuaian antara harapan dan kenyataan yang diterima, (2) Repeat purchase, Konsumen menggunakan jasa
Gojek secara terus-menerus dan menjadikan Gojek sebagai pemberi jasa pelayanan yang paling dipercaya akan kualitasnya, (3) Word of Mouth/Buzz, Memasang reputasi Gojek untuk memberi tahu orang lain mengenai kualitas yang baik, (4) Evangelism, Meyakinkan orang lain untuk menggunakan jasa Gojek berdasarkan pengalaman positif selama menggunakan jasa Gojek, (5) Ownership, Merasa bertanggung jawab atas kesuksesan Gojek yang berkelanjutan karena keikutsertaan konsumen dalam memberikan respon positif terhadap Gojek.

\section{TEKNIK ANALISIS DATA}

Dalam penelitian ini teknik analisis data yang digunakan adalah Uji Validitas Uji Reliabilitas. Pada Uji Goodness of Fit terdapat Uji F dan Uji Koefisien Determinasi Berganda (R2). Pada Uji Asumsi Klasik terdapat Uji Normalitas, Uji Multikolinearitas dan Uji Heterokesdatisitas dan Analisis jalur (path analysis) untuk menguji korelasi, regresi dan jalur sehingga dapat diketahui untuk sampai pada variabel dependen terakhir, harus lewat jalur langsung atau melalui variabel intervening

\section{HASIL DAN PEMBAHASAN}

\section{Analisis Jalur (Path Analysis)}

\section{0,122}

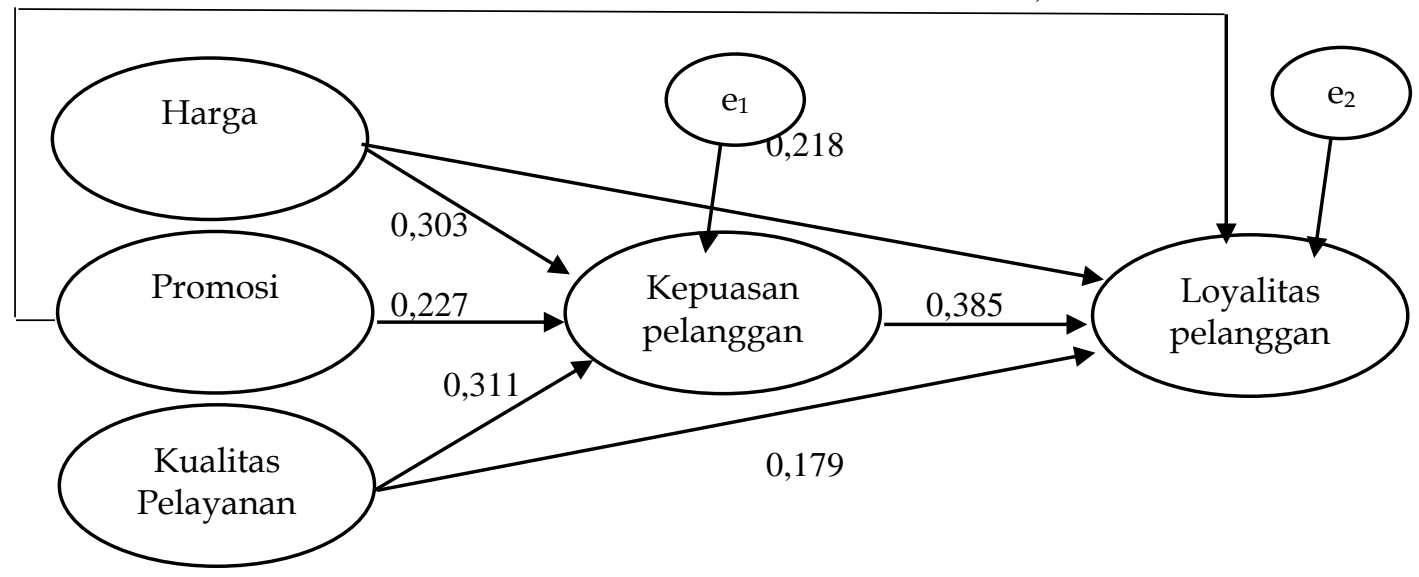

Gambar 1. Hasil Analisis Diagram Jalur

Gambar 1 menunjukkan besaran nilai koefisien jalur untuk masing-masing variabel dependen. Dengan demikian, persamaan sub-struktur untuk diagram jalur di atas dapat diformulasikan sebagai berikut

$\mathrm{KP}=0,303 \mathrm{H}+0,227 \mathrm{P}+0,311 \mathrm{~K} \cdot \mathrm{Pel}+\mathrm{e} 1$

$\mathrm{LP}=0,218 \mathrm{H}+0,122 \mathrm{P}+0,179 \mathrm{~K} \cdot \mathrm{Pel}+0,385 \mathrm{KP}+\mathrm{e} 2 \ldots$ (2)

Dari persamaan model 1 dan model 2 pada persamaan di atas, analisis standardized coefficient untuk masingmasing model dapat dijelaskan sebagai berikut:

\section{Analisis Regresi Model 1}

Pada model 1, nilai standardized coefficient untuk variabel $\mathrm{H}$ positif sebesar 0,303 menunjukkan adanya hubungan yang searah. Yang berarti, jika $\mathrm{H}$ meningkat maka variabel KP menjadi meningkat dengan asumsi variable lain konstan. Selanjutnya besarnya standardized coefficient untuk variabel $\mathrm{P}$ positif sebesar 0,227 menunjukkan adanya hubungan yang searah. Yang berarti, jika $\mathrm{P}$ meningkat maka variabel $\mathrm{KP}$ menjadi meningkat dengan asumsi variabel lain konstan. Serta besarnya standardized coefficient untuk variabel K.Pel positif sebesar 0,311 menunjukkan adanya hubungan yang searah. Yang berarti, jika K.Pel

meningkat maka variabel KP menjadi meningkat dengan asumsi variabel lain konstan. Pada model 1 diketahui variabel K.Pel memiliki pengaruh lebih besar terhadap 
variabel KP, karena memiliki nilai standardized coefficient paling tinggi.

\section{Analisis Regresi Model 2}

Pada model 2, nilai standardized coefficient untuk variabel $\mathrm{H}$ positif sebesar 0,218 menunjukkan adanya hubungan yang searah. Yang berarti, jika $\mathrm{H}$ meningkat maka variabel LP menjadi meningkat dengan asumsi variabel lain konstan. Selanjutnya besarnya standardized coefficient untuk variabel $\mathrm{P}$ positif sebesar 0,122 menunjukkan adanya hubungan yang searah. Yang berarti, jika $\mathrm{P}$ meningkat maka variabel LP menjadi meningkat dengan asumsi variabel lain konstan. Serta besarnya standardized coefficient untuk variabel K.Pel positif sebesar 0,179 menunjukkan adanya hubungan yang searah. Yang berarti, jika K.Pel meningkat maka variabel LP juga meningkat dengan asumsi variabel lain konstan. Sedangkan besarnya standardized coefficient untuk variabel KP positif sebesar 0,385 menunjukkan adanya hubungan yang searah. Yang berarti, jika KP meningkat maka variabel loyalitas pelanggan juga meningkat dengan asumsi variabel lain konstan. Pada model 2 diketahui variabel KP paling berpengaruh terhadap variabel LP, karena memiliki nilai standardized coefficient paling tinggi.

\section{Uji Hipotesis (Uji t)}

Tabel 1. Pengujian Hipotesis Penelitian

\begin{tabular}{cccccc}
\hline Hipotesis & Hubungan Variabel & $\begin{array}{c}\text { Standardized } \\
\text { Coefficient }\end{array}$ & Sig-value & Sig. $a$ & Putusan* \\
\hline 1 & $\mathrm{H} \rightarrow \mathrm{KP}$ & 0,303 & 0,002 & 0,05 & Positif-Signifikan \\
2 & $\mathrm{P} \rightarrow \mathrm{KP}$ & 0,227 & 0,019 & 0,05 & Positif-Signifikan \\
3 & $\mathrm{~K} . \mathrm{Pel} \rightarrow \mathrm{KP}$ & 0,311 & 0,001 & 0,05 & Positif-Signifikan \\
4 & $\mathrm{H} \rightarrow$ LP & 0,218 & 0,022 & 0,05 & Positif-Signifikan \\
5 & $\mathrm{P} \rightarrow$ LP & 0,122 & 0,183 & 0,05 & Positif- Tidak Signifikan \\
6 & $\mathrm{~K} . \mathrm{Pel} \rightarrow$ LP & 0,179 & 0,044 & 0,05 & Positif-Signifikan \\
7 & $\mathrm{KP} \rightarrow$ LP & 0,385 & 0,000 & 0,05 & Positif-Signifikan \\
\hline
\end{tabular}

Hasil pengujian hipotesis penelitian yang ditunjukkan pada tabel 1 dapat dijelaskan secara runtut sebagai berikut:

Menurut Tjiptono (2012) harga memiliki dua peranan utama dalam proses pengambilan keputusan para pembeli yaitu peranan alokasi dan peranan informasi. Harga (price) adalah jumlah uang yang dibebankan atau dikenakan atas sebuah produk atau produk. Berdasarkan hasil pengujian hipotesis penelitian pada tabel 1, pengaruh $\mathrm{H}$ terhadap KP menghasilkan nilai koefisien (Standardized Coefficient) positif sebesar 0,303 dan Sigvalue sebesar 0,002. Oleh karena itu menurut ketentuan yang telah ditetapkan bahwa Sig-value 0,002 < Sig. tolerance 0,05 yang membuktikan adanya pengaruh signifkan. Hasil penelitian ini mendukung penelitian Fernandes (2017), Yulianto et al (2016) dan Khakim et al (2014) yang menemukan bahwa terdapat pengaruh yang positif dan signifikan antara harga terhadap kepuasan pelanggan. Hal ini menunjukkan bahwa harga merupakan unsur yang penting bagi setiap perusahaan terutama perusahaan yang bergerak di bidang penyedia jasa.

Promosi merupakan suatu ungkapan dalam arti luas tentang kegiatan-kegiatan yang secara efektif dilakukan oleh perusahaan (penjual) untuk mendorong konsumen membeli produk atau jasa yang ditawarkan (Sukirno dan Poerwanto, 2014:194). Berdasarkan hasil pengujian hipotesis penelitian pada tabel 1, pengaruh $\mathrm{P}$ terhadap KP menghasilkan nilai koefisien (Standardized Coefficient) positif sebesar 0,227 dan Sig-value sebesar 0,019. Oleh karena itu menurut ketentuan yang telah ditetapkan bahwa Sig-value $0,019<$ Sig. tolerance 0,05 yang membuktikan adanya pengaruh signifkan. Hasil penelitian ini mendukung penelitian Fernandes (2017), Yulianto et al (2016) dan Tjahjaningsih (2013) menemukan bahwa terdapat pengaruh positif dan signifikan antara promosi terhadap kepuasan pelanggan. Hal ini menunjukkan bahwa promosi merupakan suatu hal yang penting dan perlu dipertimbangkan untuk mencapai kepuasan konsumen. Promosi merupakan suatu alat yang digunakan perusahaan untuk berkomunikasi dengan konsumen dan kegiatan promosi yang dilakukan perusahaan dapat mendorong konsumennya merasa puas atas produk yang ditawarkan atau diberikan oleh perusahaan.

Kualitas Pelayanan menurut (Christina, 2013) merupakan perspektif konsumen dalam jangka panjang dan merupakan evaluasi kognitif dari jasa transfer. Perusahaan yang memberikan komitmen pada kualitas dan secara konsisten memberikan kualitas pelayanan akan menikmati keunggulan persaingan sehingga perusahaan dapat dengan mudah membina loyalitas pelanggan dan membina hubungan pelanggan dengan sukses. Berdasarkan hasil pengujian hipotesis penelitian pada tabel 1, pengaruh K.Pel terhadap KP menghasilkan nilai koefisien (Standardized Coefficient) positif sebesar 0,311 dan Sig-value sebesar 0,001. Oleh karena itu menurut ketentuan yang telah ditetapkan bahwa Sig-value 0,001 < 
Sig. tolerance 0,05 yang membuktikan adanya pengaruh signifkan. Hasil penelitian ini mendukung penelitian Azhar et al (2019), Novianti et al (2018), Fernandes (2017), Yulianto et al (2016), Dennisa (2016) dan Sembiring et al (2014) yang menemukan bahwa terdapat positif dan signifikan antara kualitas pelayanan terhadap kepuasan pelanggan. Hal ini menunjukkan bahwa kualitas pelayanan sangat penting bagi perusahaan, dengan adanya kualitas pelayanan yang baik yang diberikan oleh Gojek akan menciptakan kepuasan bagi para konsumennya. Setelah konsumen merasa puas dengan jasa yang diterimanya, konsumen akan membandingkan pelayanan yang diberikan.

Harga (price) adalah jumlah uang yang dibebankan atau dikenakan atas sebuah produk atau produk. Dengan kata lain harga merupakan sebuah nilai yang harus ditukarkan dengan produk yang dikehendaki konsumen. (Swasta, 2013). Berdasarkan hasil pengujian hipotesis penelitian pada tabel 11, pengaruh $\mathrm{H}$ terhadap LP menghasilkan nilai koefisien (Standardized Coefficient) positif sebesar 0,218 dan Sig-value sebesar 0,022. Oleh karena itu menurut ketentuan yang telah ditetapkan bahwa Sig-value $0,022<$ Sig. tolerance 0,05 yang membuktikan adanya pengaruh signifkan. Hasil penelitian ini mendukung penelitian Yulianto et al (2016) dan Khakim et al (2014) yang menemukan bahwa terdapat pengaruh positif dan signifikan antara harga terhadap loyalitas pelanggan, sedangkan hasil berbeda dalam penelitian yang dilakukan Fernandes (2017) yang menunjukkan bahwa terdapat pengaruh tidak signifikan antara harga terhadap loyalitas pelanggan. Hal ini menunjukkan bahwa harga sangat penting bagi perusahaan dalam membangun loyalitas pelanggan. Dengan harga yang tinggi harus dilengkapi dengan kualitas dan manfaat produk yang ditawarkan.

Promosi adalah suatu bentuk komunikasi pemasaran, yaitu aktivitas pemasaran yang berusaha menyebarkan informasi, mempengaruhi, membujuk dan atau mengingatkan pasar sasaran atas perusahaan dan produknya agar konsumen bersedia menerima, membeli, dan loyal pada produk yang ditawarkan perusahaan (Tjiptono, 2014:229). Berdasarkan hasil pengujian hipotesis penelitian pada tabel 1, pengaruh $\mathrm{P}$ terhadap LP menghasilkan nilai koefisien (Standardized Coefficient) positif sebesar 0,122 dan Sig-value sebesar 0,183. Oleh karena itu menurut ketentuan yang telah ditetapkan bahwa Sig-value 0,183 > Sig. tolerance 0,05 yang membuktikan adanya pengaruh signifkan. Hasil penelitian ini mendukung penelitian Fernandes (2017) yang menemukan bahwa bahwa terdapat pengaruh tidak signifikan antara promosi terhadap loyalitas pelanggan, sedangkan hasil yang berbeda ditunjukkan dalam penelitian yang dilakukan oleh Yulianto et al (2016) dan Tjahjaningsih (2013) yang menemukan bahwa terdapat pengaruh positif dan signifikan antara promosi terhadap loyalitas pelangganan. Hal ini menunjukkan bahwa Gojek perlu meningkatkan kegiatan promosi secara rutin untuk menarik perhatian pelanggan agar para pelanggan akan tetap setia menggunakan jasa Gojek

Menurut Parasuraman dalam Lupiyoadi (2013) mengatakan bahwa kualitas pelayanan yaitu seberapa jauh perbedaan antara kenyataan dan harapan pelanggan atas pelayanan yang mereka terima Berdasarkan hasil pengujian hipotesis penelitian pada tabel 1, pengaruh K.Pel terhadap LP menghasilkan nilai koefisien (Standardized Coefficient) positif sebesar 0,179 dan Sigvalue sebesar 0,044. Oleh karena itu menurut ketentuan yang telah ditetapkan bahwa Sig-value 0,044 < Sig. tolerance 0,05 yang membuktikan adanya pengaruh signifkan. Hasil penelitian ini mendukung penelitian Azhar et al (2019), Novianti et al (2018), Yulianto et al (2016), Dennisa (2016) dan Sembiring et al (2014) yang menunjukkan bahwa terdapat pengaruh positif dan signifikan antara kualitas pelayanan terhadap loyalitas pelanggan. sedangkan hasil berbeda dalam penelitian yang dilakukan Fernandes (2017) yang menunjukkan bahwa terdapat pengaruh tidak signifikan antara harga terhadap loyalitas pelanggan. Hal ini menunjukkan bahwa kualitas pelayanan merupakan hal yang penting bagi pelanggan sebagai bahan penilaian terhadap suatu perusahaan.

Menurut Kotler dan Armstrong (2010:314) harga adalah sejumlah uang yang dibebankan atas suatu produk atau jasa, atau jumlah dari nilai yang ditukar konsumen atas manfaat-manfaat karena memiliki atau menggunakan produk atau jasa. Berdasarkan hasil pengujian hipotesis penelitian pada tabel di atas, harga $(\mathrm{H})$ memiliki pengaruh yang positif terhadap kepuasan pelanggan (KP) dan kepuasan pelanggan (KP) berpengaruh positif terhadap loyalitas pelanggan (LP). Diketahui besarnya pengaruh langsung antara harga $(\mathrm{H})$ terhadap loyalitas pelanggan (LP) sebesar 0,218. Sedangkan untuk mengetahui besarnya pengaruh tidak langsung, maka dapat dilakukan perkalian antara nilai beta promosi $(\mathrm{P})$ terhadap kepuasan pelanggan $(\mathrm{KP})$ dan nilai beta kepuasan pelanggan $(\mathrm{KP})$ terhadap loyalitas pelanggan (LP) yaitu : 0,218 x 0,385= 0,083 . Maka pengaruh total yang diberikan promosi $(\mathrm{P})$ terhadap loyalitas pelanggan (LP) dapat diketahui dengan menjumlah pengaruh langsung dan pengaruh tidak langsung yaitu : $0,218+0,083=0,301$. Dengan demikian dapat diketahui bahwa besarnya pengaruh langsung adalah 0,218 dan besarnya pengaruh tidak langsung adalah 0,301 yang berarti pengaruh tidak langsung lebih besar dibandingkan dengan pengaruh langsung, sehingga secara tidak langsung harga $(\mathrm{H})$ berpengaruh signifikan 
terhadap loyalitas pelanggan (LP) melalui kepuasan pelanggan (KP). loyalitas pelanggan (LP) melalui kepuasan pelanggan (KP) adalah signifikan. Hasil penelitian ini mendukung penelitian Fernandes (2017) yang menyimpulkan bahwa kepuasan pelanggan dapat memediasi hubungan antara harga terhadap loyalitas pelanggan.

Promosi merupakan suatu ungkapan dalam arti luas tentang kegiatan-kegiatan yang secara efektif dilakukan oleh perusahaan (penjual) untuk mendorong konsumen membeli produk atau jasa yang ditawarkan (Sukirno dan Poerwanto, 2014:194). Berdasarkan hasil pengujian hipotesis penelitian pada tabel di atas, promosi (P) memiliki pengaruh yang positif terhadap kepuasan pelanggan (KP) dan kepuasan pelanggan (KP) berpengaruh positif terhadap loyalitas pelanggan (LP). Diketahui besarnya pengaruh langsung antara promosi $(\mathrm{P})$ terhadap loyalitas pelanggan (LP) sebesar 0,122. Sedangkan untuk mengetahui besarnya pengaruh tidak langsung, maka dapat dilakukan perkalian antara nilai beta promosi $(\mathrm{P})$ terhadap kepuasan pelanggan $(\mathrm{KP})$ dan nilai beta kepuasan pelanggan (KP) terhadap loyalitas pelanggan (LP) yaitu : 0,122 x 0,385=0,046. Maka pengaruh total yang diberikan promosi (P) terhadap loyalitas pelanggan (LP) dapat diketahui dengan menjumlah pengaruh langsung dan pengaruh tidak langsung yaitu : $0,122+0,046=0,168$. Dengan demikian dapat diketahui bahwa besarnya pengaruh langsung adalah 0,122 dan besarnya pengaruh tidak langsung adalah 0,168 yang berarti pengaruh tidak langsung lebih besar dibandingkan dengan pengaruh langsung, sehingga secara tidak langsung promosi $(\mathrm{P})$ berpengaruh signifikan terhadap loyalitas pelanggan (LP) melalui kepuasan pelanggan (KP). Hasil penelitian ini mendukung penelitian Novianti et al (2018), Fernandes (2017), dan Tjahjaningsih (2013) yang menyimpulkan bahwa kepuasan pelanggan dapat memediasi hubungan antara promosi terhadap loyalitas pelanggan.

Menurut Parasuraman dalam Lupiyoadi (2013) mengatakan bahwa kualitas pelayanan yaitu seberapa jauh perbedaan antara kenyataan dan harapan pelanggan atas pelayanan yang mereka terima. Berdasarkan hasil pengujian hipotesis penelitian pada tabel di atas, kualitas pelayanan (K.Pel) memiliki pengaruh yang positif terhadap kepuasan pelanggan (KP) dan kepuasan pelanggan (KP) berpengaruh positif terhadap loyalitas pelanggan (LP). Diketahui besarnya pengaruh langsung antara kualitas pelayanan (K.Pel) terhadap loyalitas pelanggan (LP) sebesar 0,122. Sedangkan untuk mengetahui besarnya pengaruh tidak langsung, maka dapat dilakukan perkalian antara nilai beta kualitas pelayanan (K.Pel) terhadap kepuasan pelanggan (KP) dan nilai beta kepuasan pelanggan (KP) terhadap loyalitas pelanggan (LP) yaitu : 0,311 x 0,385=0,119. Maka pengaruh total yang diberikan kualitas pelayanan (K.Pel) terhadap loyalitas pelanggan (LP) dapat diketahui dengan menjumlah pengaruh langsung dan pengaruh tidak langsung yaitu : $0,311+0,119=0,430$. Dengan demikian dapat diketahui bahwa besarnya pengaruh langsung adalah 0,311 dan besarnya pengaruh tidak langsung adalah 0,430 yang berarti pengaruh tidak langsung lebih besar dibandingkan dengan pengaruh langsung, sehingga secara tidak langsung kualitas pelayanan (K.Pel) berpengaruh signifikan terhadap loyalitas pelanggan (LP) melalui kepuasan pelanggan (KP). Hasil penelitian ini mendukung penelitian Novianti et al (2018), Fernandes (2017) dan Sembiring et al (2014) yang menyimpulkan bahwa kepuasan pelanggan dapat memediasi hubungan antara promosi terhadap loyalitas pelanggan.

Kepuasan konsumen adalah evaluasi purnabeli antara persepsi terhadap kinerja altenatif produk atau jasa yang dipilih memenuhi atau melebihi harapan. Apabila persepsi terhadap kinerja tidak bisa memenuhi harapan, maka yang terjadi adalah ketidak puasan (Tjiptono, 2014). Berdasarkan hasil pengujian hipotesis penelitian pada tabel 1, pengaruh KP terhadap LP menghasilkan nilai koefisien (Standardized Coefficient) positif sebesar 0,285 dan Sig-value sebesar 0,000. Oleh karena itu menurut ketentuan yang telah ditetapkan sebelumnya bahwa Sig-value $0,000<$ Sig. tolerance 0,05 yang membuktikan adanya pengaruh signifkan. Hasil penelitian ini mendukung penelitian Azhar et al (2019), Fernandes (2017), Khakim et al (2014), Dennisa (2016) dan Sembiring et al (2014) yang menemukan bahwa terdapat pengaruh positif dan signifikan antara kepuasan pelanggan terhadap loyalitas pelanggan. Hal ini menunjukkan bahwa kepuasan pelanggan merupakan faktor penunjang yang sangat berpengaruh bagi upaya peningkatan loyalitas pelanggan. Pada saat pelanggan merasakan suatu kepuasan maka akan timbul loyalitas. Sehingga semakin tinggi kepuasan pelanggan diharapkan memberikan dampak positif pada peningkatan loyalitas pelanggan.

\section{PENUTUP}

\section{Simpulan}

Harga (keterjangkauan harga, kesesuaian dengan kualitas, daya saing harga, kesesuaian dengan manfaat), Promosi (Promosi konsumen, Promosi dagang, Promosi wiraniaga) dan Kualitas pelayanan (tangible, reliability, responsiveness, assurance, dan emphaty) mempunyai pengaruh signifikan yang cukup kuat terhadap kepuasan pelanggan. Harga (keterjangkauan harga, kesesuaian dengan kualitas, daya saing harga, kesesuaian dengan 
manfaat), Kualitas pelayanan (tangible, reliability, responsiveness, assurance, dan emphaty) dan Kepuasan pelanggan (kepuasan terhadap jasa, menggunakan kembali, mereokmendasikan, harapan terpenuhi) mempunyai pengaruh signifikan yang cukup kuat terhadap loyalitas pelanggan sedangkan Promosi (Promosi konsumen, Promosi dagang, Promosi wiraniaga) mempunyai pengaruh yang tidak signifikan terhadap loyalitas pelanggan. Hal ini mencerminkan bahwa semakin kurang kegiatan promosi yang dilakukan oleh Gojek maka akan semakin menurunkan tingkat loyalitas pelanggannya. Harga (keterjangkauan harga, kesesuaian dengan kualitas, daya saing harga, kesesuaian dengan manfaat), Promosi (Promosi konsumen, Promosi dagang, Promosi wiraniaga) dan Kualitas pelayanan (tangible, reliability, responsiveness, assurance, dan emphaty) mempunyai pengaruh signifikan yang lebih besar terhadap loyalitas pelanggan ketika dimediasi kepuasan pelanggan

\section{Saran}

Bagi pihak Gojek diharapkan menetapkan harga yang sesuai dengan manfaat dan kualitas, agar dapat meningkatkan kepuasan pelanggan, karena telah terbukti bahwa harga mempunyai pengaruh terhadap kepuasan pelanggan dan loyalitas pelanggan. Bagi pihak Gojek diharapkan untuk melakukan strategi promosi yang semakin baik dan efektif yang dapat meningkatkan kepuasan pelanggan, karena telah terbukti bahwa promosi mempunyai pengaruh terhadap kepuasan pelanggan dan loyalitas pelanggan. Bagi pihak Gojek diharapkan untuk menjaga dan meningkatkan kualitas pelayanan yang telah ada, agar dapat meningkatkan kepuasan pelanggan, karena telah terbukti bahwa kualitas pelayanan mempunyai pengaruh terhadap kepuasan pelanggan dan loyalitas pelanggan. Bagi pihak Gojek diharapkan dapat memenuhi kepuasan pelanggan dengan kebutuhan dan keinginan yang sesuai harapan pelanggan, agar dapat meningkatkan loyalitas pelanggannya, karena telah terbukti bahwa kepuasan pelanggan memiliki pengaruh terhadap loyalitas pelanggan.

\section{DAFTAR PUSTAKA}

Azhar, Muhammad Elfi, dkk. (2019). "The Role of Maketing Mix and Service Quality on Tourist Satisfaction and Loyalty at Samosir". Jurnal. Universitas Muhammadiyah Sumatera Utara

Basu, S dan Irawan. (2013). Manajemen Pemasaran Modern. Liberty : Yogyakarta.

Christina, W. (2013). Manajemen Ritel. Jakarta: Salemba Empat.
Dennisa dan Eugenia, A. (2016). “Analisis Pengaruh Kualitas Produk, Kualitas Layanan, dan Citra Merek terhadap Loyalitas Pelanggan melalui Kepuasan Pelanggan sebagai Variabel Intervening (Studi pada Klinik Kecantikan Cosmedic Semarang)". Jurnal. Universitas Diponegoro

Fernandes dan Adji, A. (2017). "The mediation effect of customer satisfaction in the relationship between service quality, service orientation, and marketing mix strategy to customer loyalty”. Jurnal. Universitas Brawijaya Malang

Gerson, R.F. (2010). Mengukur Kepuasan Pelanggan: Panduan Menciptakan Pelayanan Bermutu, ed 1. PPM-Bisnis2030. Jakarta.

Khakim, Fathoni dan Minarsih. (2014). "Pengaruh Kualitas Pelayanan, Harga dan Kepercayaan Terhadap Loyalitas Pelanggan dengan Variabel Kepuasan Pelanggan sebagai Variabel Intervening pada Pizza Hut Cabang Simpang Lima”. Jurnal. Universitas Pandanaran Semarang.

Kotler, P dan Kevin, L (2016). Marketing Managemen, 15th ed, Pearson Education,Inc.

Kotler, P \& Armstrong. (2008). Prinsip-Prinsip Pemasaran, ed 12. Jilid I. Jakarta:Erlangga

(2010). Principles of Marketing, 13th ed. New Jersey: Prentice-Hall, Inc.

Lupiyoadi, R. (2013). Manajemen Pemasaran Jasa Berbasis Kompetensi, ed 3. Jakarta: Salemba Empat.

Novianti, dkk.(2018). “Kepuasan Pelanggan Memediasi Pengaruh Kualitas Pelayanan Dan Promosi Terhadap Loyalitas Pelanggan”. Jurnal. Universitas Satya Negara

Sembiring, I. (2014). “Pengaruh Kualitas Produk Dan Kualitas Pelayanan Terhadap Kepuasan Pelanggan Dalam Membentuk Loyalitas Pelanggan (Studi pada Pelanggan McDonald's MT.Haryono Malang)". Jurnal. Unversitas Brawijaya Malang.

Sugiyono. (2007). Metodologi Penelitian Bisnis, PT. Gramedia, Jakarta

(2008). Metode Penelitian Bisnis (Kuantitatif, Kualitatif dan $R \& D)$. Alfabeta. Bandung.

Sukirno, Zakaria dan Poerwanto. (2014). Komunikasi Bisnis. Penerbit. Pustaka Pelajar, Yogyakarta.

Tjahjaningsih, E. (2013). "Pengaruh Citra Dan Promosi Terhadap Kepuasan Pelanggan Serta Dampaknya Terhadap Loyalitas Pelanggan (Studi Pada Pelanggan Supermarket Carrefour Di Semarang)". Jurnal. Universitas Stikubank.

Tjiptono, F. (2012). Strategi Pemasaran, ed. 3, Andi Offset. Yogyakarta 
JUPE Volume 08 Nomor 03 Tahun 2020, 86 - 94

(2008). Strategi Bisnis Pemasaran. Andi Offset. Yogyakarta.

(2014). Pemasaran Jasa: Prinsip, Penerapan, dan Penelitian, ed 1. Andi Offset. Yogyakarta.

Yulianto, I. (2016). "Pengaruh Promosi Penjualan, Harga Dan Kualitas Pelayanan Terhadap Kepuasan Dan Loyalitas Konsumen ( Studi Kasus Counter Handphone Di Shiba Communication )'. Jurnal. Universitas Pandanaran Semarang 